\title{
Brown Fat - Hotting up Again
}

\author{
Paul Trayhurn \\ Obesity Biology Research Unit, School of Clinical Sciences, University of Liverpool, Duncan Building, Liverpool, UK
}

For a decade or so from the late 1970s brown adipose tissue was a key focus of obesity research. The concept that adaptive changes in energy expenditure are important in the regulation of energy balance, with reductions in thermogenesis as a major factor in the development of obesity, had taken centre stage. This was based on some pivotal observations from studies on experimental animals. Brown adipose tissue provided the missing locus for thermogenesis, with the molecular mechanism by which heat is produced being elucidated. Evidence in support of the idea that brown adipose tissue thermogenesis is a major component of adaptive energy expenditure in laboratory rodents accumulated rapidly in the 1980s from a range of studies. However, there was considerable scepticism on the relevance to human energetics (beyond the newborn) and to the aetiology of obesity in particular. Alexander Pope's aphorism 'The Proper Study of Mankind is Man' resonated strongly. But the situation has changed dramatically over the past couple of years, with a surge of interest in brown fat in humans and its potential role in adult energy metabolism.

Brown adipose tissue (or brown fat), which has been proposed to be part of a single 'adipose organ' [1], was first described in 1551 by the Swiss naturalist Conrad Gessner and subsequently termed the 'hibernating gland'. However, it was not until some three centuries later through the work of Robert Emrie Smith in the 1960s that brown fat was clearly recognised as a thermogenic tissue [2]. This was in the context of thermoregulation - as 'non-shivering thermogenesis'. The quantitative importance of brown adipose tissue to total heat production was considered to be modest until blood flow measurements with radioactively labelled microspheres by Foster and Frydman [3,4] showed that more than half of the heat generated by non-shivering thermogenesis in rats acclimated to the cold is due to brown fat. These critical observations came at the time when the controlled uncoupling of mitochondria through a proton conductance pathway specific to brown adipose tissue was being demonstrated as the primary mechanism by which adaptive heat is produced $[5,6]$.
The groups exploring in experimental animals the thesis that adaptive changes in energy expenditure are central to the regulation of energy balance and underlie the development of obesity were considering several tissue locations and biochemical mechanisms by which this might occur. The tissues of primary interest were skeletal muscle and the liver, while processes such as substrate cycles (also known as futile cycles), protein turnover and $\mathrm{Na}^{+}$transport across the plasma membrane were all considered as candidate mechanisms. None, however, were thought to be sufficiently important in terms of the amount of heat that they might produce. The demonstration of the quantitative importance of brown fat to non-shivering thermogenesis in rats suggested that this tissue could be the key site of adaptive thermogenesis beyond the demands of thermoregulation. In other words, it might be involved in other forms of adaptive heat production, such as diet-induced thermogenesis.

Two pivotal observations made in 1978 and 1979 directly linked brown adipose tissue to obesity. In the first, HimmsHagen and Desautels [7] showed, using biochemical indices, that the thermogenic activity of brown fat mitochondria was reduced in obese $(o b / o b)$ mice relative to their lean siblings [7]. They also demonstrated impaired brown fat activation in the obese mutants in response to cold. The second pivotal observation came from the work of Rothwell and Stock [8] and Brooks et al. [9], who showed in rats exhibiting substantial levels of diet-induced thermogenesis following the consumption of a 'cafeteria diet' that the activity and capacity of brown fat were increased. These studies led to a radical new perspective on brown adipose tissue function and of energy exchange in small mammals. They were followed by the demonstration that changes in brown adipose tissue activity occur in a wide range of situations and model systems, from different forms of obesity to lactation, fasting and other types of nutritional intervention $[10,11]$.

One of the further critical developments was the discovery that a specific protein, termed uncoupling protein (now known as uncoupling protein-1 (UCP1)), located in the inner mem-

\section{KARGER}

Fax +497614520714

Information@Karger.de

www.karger.com (c) 2009 S. Karger GmbH, Freiburg

Accessible online at:

www.karger.com/ofa
Professor Paul Trayhurn, FRSE Obesity Biology Research Unit

School of Clinical Sciences, University of Liverpool

Duncan Building, Liverpool L69 3GA, UK

Tel. +44 151 706-4033, Fax -5802

p.trayhurn@liverpool.ac.uk 
brane of brown adipose tissue mitochondria is responsible for the generation of heat in the tissue through the uncoupling of oxidative phosphorylation $[12,13]$. This occurs by the dissipation of the proton gradient by bypassing the normal coupling to ATP synthesis [5]. UCP1 is found uniquely in brown adipose tissue, or more specifically in brown adipocytes. As such, detection of the protein (or its mRNA) provides a definitive molecular tool for differentiating brown adipocytes from white adipocytes and other cells in which lipid may be deposited [14].

Despite the growing body of evidence linking brown adipose tissue to energy metabolism and obesity in rodents, the picture in humans remained unclear, and there were two distinct reasons for this. Firstly, there was - and still is - trenchant debate about whether a reduction in energy expenditure, particularly of thermogenesis, is an important factor in the development of obesity in humans. This was linked to the view that adaptive heat production is not a substantial component of normal human energy expenditure. The second debate centred on whether brown adipose tissue occurs in humans - other than in neonates and infants where it is well recognised to be present, reflecting the thermal challenges that the newborn of many mammalian species have to confront. In the modern world, of course, as well as historically, humans use clothing, blankets and external heat, to minimise the extent to which the newborn are exposed to low temperature stress, obviating the need for thermoregulatory thermogenesis. In the case of adults, studies in the 1980s on patients with phaeochromocytoma in which there is a hypersecretion of catecholamines showed an apparent activation of brown adipose tissue $[15,16]$. In addition, evidence for the presence of immunoreactive UCP1, or its mRNA, was reported in adipose tissue of adult humans of all ages, indicating the presence of active brown fat [17-21].

These observations on humans were largely over-looked, perhaps being viewed as reflecting special circumstances (or a small, localised cluster of cells) rather than indicating the general situation. Indeed, there have been frequent assertions that brown adipose tissue is absent from adult humans. Recent findings have, however, very much put the tissue back on the map, with interest in brown fat in humans being re-ignited from an unexpected direction - nuclear medicine. Fluorodeoxyglucose positron emission tomography (FDG-PET) is used to track the metastasis of tumours, essentially by locating areas where there is a high uptake of glucose [22]. Its application has led to the probable identification of brown adipose tissue based on areas of high glucose uptake with a distribution pattern consistent with what had been earlier considered to represent the tissue [22]. These regions include the supraclavicular, neck, paravertebral and suprarenal areas, and the FDG-PET technique has shown that glucose uptake into the presumptive brown fat sites is stimulated by cold and is sympathetically mediated, both observations consistent with genuine brown fat [22].
However, the FDG-PET studies do not of themselves definitively identify brown adipose tissue in humans - which requires the parallel detection of UCP1 in the tissue sites. This was achieved in a group of reports published in a recent issue of the New England Journal of Medicine (April 9, 2009). In one study, brown fat was putatively identified by FDG-PET in a region from the neck to the thorax and subsequently confirmed by immunostaining for UCP1 [23]. This study suggested that women had more brown fat than men, and that the amount was inversely correlated with BMI. It also showed a relationship with age, external temperature and the use of beta-blockers, consistent with known influences on the activity and capacity of the tissue [23]. Another study demonstrated a substantial increase (15-fold) in the uptake of glucose in the paracervical and supraclavicular adipose tissue in adult subjects in response to cold exposure [24]. In this study, both UCP1 and UCP1 mRNA were detected in multilocular fat cells in biopsy samples from these major sites of glucose uptake, again providing powerful evidence for the presence of brown fat and importantly its activation by cold [24]. FDG-PET also allowed brown fat to be putatively identified in another study employing cold exposure, with subjects being exposed to mild cold $\left(16{ }^{\circ} \mathrm{C}\right)$ as compared to those maintained at thermoneutrality $\left(22{ }^{\circ} \mathrm{C}\right)$ [25]. A relationship was again shown with BMI and percentage body fat, with obese and overweight subjects exhibiting lower apparent activity [25].

The most recent report comes from a collaboration between laboratories in Ancona and Stockholm. This study, which represents the most detailed and comprehensive investigation to date on whether brown adipocytes are indeed present in adult humans, has employed a combination of approaches to examine samples of adipose tissue removed from the neck of patients during surgery for thyroid diseases [26]. Distinct 'islands' of small multilocular adipocytes were found to stain for UCP1 in up to one third of the patients and these were surrounded by larger unilocular cells which were UCP1-negative. The older patients had a lower proportion of UCP1 immunoreactivity. The UCP1-positive cells exhibited the classical ultrastructural appearance of brown adipocytes, with numerous mitochondria characterised by an extensive cristae structure [26]. The islands of UCP1-staining cells also showed dense sympathetic innervation, in contrast to the adjacent white adipose tissue areas, and the presence of distinct brown adipocyte precursor cells.

The reports that have appeared over the past few months unambiguously demonstrate that brown adipose tissue is present and active in many adult humans. It should, however, be noted that brown fat was found in only a minority of subjects investigated in some of the studies [23, 26]. Preparation for surgery, including fasting and anaesthesia, is unlikely to affect the detection of UCP1 and the other diagnostic features of brown fat. The relationship with age and BMI is part of 
the explanation, but it is clearly important to probe further in order to understand the basis for the variability and its physiological significance.

From the perspective of human energetics, the question of the probable quantitative contribution of brown adipose tissue thermogenesis to overall energy expenditure is still to be resolved - but it is likely that it is at best modest. This is central to the other key issue of whether reductions in brown fat activity may play a causal role in the development of obesity. While the clear identification of brown adipose tissue in adults humans has raised expectations that the tissue may be energetically important, caution is warranted. Nevertheless, the exciting recent developments will re-kindle interest in the often discussed possibility of treating obesity through agents directed specifically to brown adipose tissue. Conceptually, such an approach does not require that inactive brown fat has a causative role in obesity, since reactivation or increased stimulation would in principle be therapeutically valuable if thermogenesis is a significant component of expenditure. Many of the old reservations are, however, still apposite and will be the subject of debate.
Interest in brown adipose tissue waned from the early 1990s, particularly in relation to the energetics of obesity, with the focus shifting to white fat on the discovery of leptin. The emergence of white adipose tissue as a major endocrine organ, with the recognition that white adipocytes secrete a multiplicity of protein hormones and signalling factors (the adipokines), has led to an intense focus on this tissue. But following recent developments it is very evident that brown adipose tissue is back - we appear set for a new 'brown fat era'.

\section{Acknowledgements}

The author is a member of COST BM0602.

\section{Disclosure}

The author has no conflicts of interest. His research is funded by grants from the Biotechnology and Biological Sciences Research Council and the Medical Research Council (UK), and through a collaboration with Unilever plc.

\section{References}

1 Cinti S: The adipose organ: morphological perspectives of adipose tissues. Proc Nutr Soc 2001;60:319328.

2 Smith RE, Horwitz BA: Brown fat and thermogenesis. Physiol Rev 1969;49:330-425.

$\checkmark 3$ Foster DO, Frydman ML: Nonshivering thermogenesis in the rat. II. Measurements of blood flow with microspheres point to brown adipose tissue as the dominant site of the calorigenesis induced by noradrenaline. Can J Physiol Pharmacol 1978;56:110-122.

4 Foster DO, Frydman ML: Tissue distribution of cold-induced thermogenesis in conscious warm- or cold-acclimated rats re-evaluated from changes in tissue blood flow: The dominant role of brown adipose tissue in the replacement of shivering by nonshivering thermogenesis. Can J Physiol Pharmacol 1979;57:257-270.

5 Nicholls DG, Locke RM: Thermogenic mechanisms in brown fat. Physiol Rev 1984;64:1-64

6 Cannon B, Nedergaard J: The biochemistry of an inefficient tissue: brown adipose tissue. Essays Biochem 1985;20:110-164

7 Himms-Hagen J, Desautels M: A mitochondrial defect in brown adipose tissue of the obese (ob/ob) mouse: reduced binding of purine nucleotides and a failure to respond to cold by an increase in binding. Biochem Biophys Res Commun 1978;83:628-634.

$\checkmark 8$ Rothwell NJ, Stock MJ: A role for brown adipose tissue in diet-induced thermogenesis. Nature 1979;281:31-35.

9 Brooks SL, Rothwell NJ, Stock MJ, Goodbody AE, Trayhurn P: Increased proton conductance pathway in brown adipose tissue mitochondria of rats exhibiting diet-induced thermogenesis. Nature 1980;286: 274-276.
10 Trayhurn P: Brown adipose tissue and energy balance; in Trayhurn P, Nicholls DG (eds): Brown Adipose Tissue. London, Edward Arnold, 1986, pp 299-388.

11 Himms-Hagen J: Brown adipose tissue thermogenesis and obesity. Prog Lipid Res 1989;28: 67-115.

12 Ricquier D: Molecular biology of brown adipose tissue. Proc Nutr Soc 1989;48:183-187.

13 Ricquier D, Casteilla L, Bouillaud F: Molecular studies of the uncoupling protein. FASEB J 1991;5: 2237-2242.

14 Trayhurn P: Uncoupling protein in brown adipose tissue: molecular differentiation of the adipose tissues. Bioch Soc Trans 1996;24:402-406.

15 Ricquier D, Néchad M, Mory G: Ultrastructural and biochemical characterization of human brown adipose tissue in pheochromocytoma. J Clin Endocrin Metab 1982;54:803-807.

16 Lean MEJ, James WPT, Jennings G, Trayhurn P: Brown adipose tissue in patients with phaeochromocytoma. Int J Obes 1986;10:219-227.

17 Bouillaud F, Combes GM, Ricquier D: Mitochondria of adult human brown adipose tissue contain a 32,000-mr uncoupling protein. Biosci Rep 1983;3: 775-780.

18 Lean MEJ, James WPT: Uncoupling protein in human brown adipose tissue mitochondria: isolation and detection by specific antiserum. FEBS Lett 1983;163:235-240.

19 Lean MEJ, James WPT, Jennings G, Trayhurn P: Brown adipose tissue uncoupling protein content in human infants, children and adults. Clin Sci 1986;71: 291-297.
20 Ricquier D: Detection of brown adipose tissue uncoupling protein mRNA in adult patients by a human genomic probe. Clin Sci 1988;75:21-27.

21 Lean MEJ: Brown adipose tissue in humans. Proc Nutr Soc 1989;48:243.

22 Nedergaard J, Bengtsson T, Cannon B: Unexpected evidence for active brown adipose tissue in adult humans. Am J Physiol Endocrinol Metab 2007;293: E444-E452.

23 Cypess AM, Lehman S, Williams G, Tal I, Rodman D, Goldfine AB, Kuo FC, Palmer EL, Tseng YH, Doria A, Kolodny GM, Kahn CR: Identification and importance of brown adipose tissue in adult humans. N Engl J Med 2009;360:1509-1517.

24 Virtanen KA, Lidell ME, Orava J, Heglind M, Westergren R, Niemi T, Taittonen M, Laine J, Savisto NJ, Enerback S, Nuutila P: Functional brown adipose tissue in healthy adults. $\mathrm{N}$ Engl $\mathrm{J}$ Med 2009;360:1518-1525.

25 van Marken Lichtenbelt WD, Vanhommerig JW, Smulders NM, Drossaerts JM, Kemerink GJ, Bouvy ND, Schrauwen P, Teule GJ: Cold-activated brown adipose tissue in healthy men. $\mathrm{N}$ Engl $\mathrm{J}$ Med 2009;360:1500-1508.

26 Zingaretti MC, Crosta F, Vitali A, Guerrieri M, Frontini A, Cannon B, Nedergaard J, Cinti S: The presence of ucp 1 demonstrates that metabolically active adipose tissue in the neck of adult humans truly represents brown adipose tissue. FASEB J 2009; DOI: 10.1096/fj.09-133546. 